KAPL-P-000171

(K97055)

$$
\text { CONF-9705/19-- }
$$

\title{
MODELING OF InGaSb THERMOPHOTOVOLTAIC CELLS AND MATERIALS
}

G. Charache, M. Zierak, et. al.

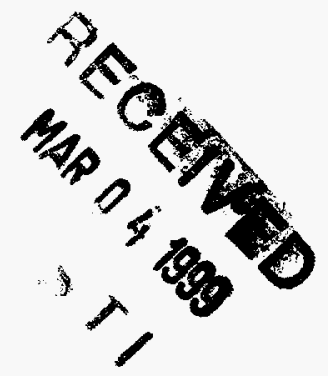

May 1997

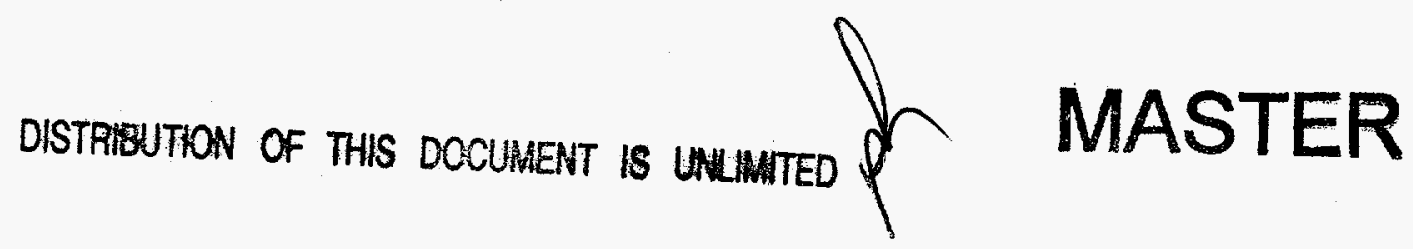

\section{NOTICE}

This report was prepared as an account of work sponsored by the United States Government. Neither the United States, nor the United States Department of Energy, nor any of their employees, nor any of their contractors, subcontractors, or their employees, makes any warranty, express or implied, or assumes any legal liability or responsibility for the accuracy, completeness or usefulness of any information, apparatus, product or process disclosed, or represents that its use would not infringe privately owned rights. 


\section{DISCLAMMER}

This report was prepared as an account of work sponsored by an agency of the United States Government. Neither the United States Goverameat nor any agency thereof, nor any of their employees, makes any warranty, express or implied. or assumes any legal liability or responsibility for the accuracy, completesess, or usefulness of any information, apparatus, produce, or process disclosed or represents that its use would not infringe privately owned rights. Refereace berein to any specific commercial product, process, or service by trade name, trademart, inanufacturer, or otherwise does not necessarily constitute or imply its eadorsemeat, recommendation. or favoring by the United States Governmeat or any ageacy thereof. The views and opinions of authors expressed herein do not necessarily state or reflect those of the United States Government or any agency thereof. 


\section{DISCLAIMER}

Portions of this document may be illegible in electronic image products. Images are produced from the best available original document. 


\title{
Modeling of InGaSb Thermophotovoltaic Cells and Materials
}

\author{
M.Zierak*, J.M.Borrego,* I.Bhat*, R.J.Gutmann* and G.Charache ${ }^{+}$ \\ *Center for Integrated Electronics and Electronic Manufacturing \\ Department of Electrical, Computer and Systems Engineering \\ Rensselaer Polytechnic Institute, Troy, New York 12180 \\ Lockheed Martin, Inc., Schenectady, New York 12301
}

\begin{abstract}
A closed form computer program has been developed for the simulation and optimization of $\mathrm{In}_{\mathrm{X}} \mathrm{Ga}_{1-\mathrm{X}} \mathrm{Sb}$ thermophotovoltaic cells operating at room temperature. The program includes material parameter models of the energy bandgap, optical absorption constant, electron and hole mobility, intrinsic carrier concentration and index of refraction for any composition of GaInSb alloys.
\end{abstract}

\section{INTRODUCTION}

Recent work on the performance of thermophotovoltaic (TPV) cells operating with black body radiation sources in the temperature range between $1000^{\circ} \mathrm{K}$ and $2000^{\circ} \mathrm{K}$ shows that the energy bandgap must be in the range between $0.5 \mathrm{eV}$ and $0.6 \mathrm{eV}^{(1)}$. Since there are no elemental or binary compound semiconductors with energy bandgap in the above range, ternary alloy systems must be considered. The two most important ternary alloy systems being considered at present are InGaAs and InGaSb. In previous publications ${ }^{(2,3)}$ the theoretical and experimental performance of TPV cells using InGaAs alloys have been presented. This paper presents the methodology we have used for calculating the performance of TPV cells using InGaSb alloys.

The methodology we have developed consists of two parts. The first part consists of modeling the material parameters which determine the performance of TPV cells such as energy bandgap, optical absorption constant, mobility of both electrons and holes, intrinsic carrier concentration and index of refraction. The second part of the methodology consists of developing a computer program which calculates the performance of TPV cells such as internal quantum efficiency, $\mathrm{J}-\mathrm{V}$ characteristics under dark and illuminated conditions using blackbody radiation source with temperature in the range between $1000^{\circ} \mathrm{K}$ and $2000^{\circ} \mathrm{K}$.

The paper is arranged in four parts. In the first part the calculation of the important material parameters of the GaInSb alloy system as a function of composition is described. The second part describes briefly the internal quantum efficiency calculation. In the third part some of the results of the simulation are presented, with special emphasis on the maximum efficiency that can be obtained for a given temperature of the blackbody radiation source. The last part deals with conclusions obtained from this modeling of the performance of GaInSb TPV cells.

\section{MODELING OF In $\mathrm{Ia}_{1-\mathrm{x}} \mathrm{Sb}$ ALLOY MATERIAL PARAMETERS}

In order to calculate the performance of $\mathrm{In}_{\mathrm{x}} \mathrm{Ga}_{1-\mathrm{X}} \mathrm{Sb}$ alloy TPV cells it is necessary to know some of the material parameters as a function of alloy composition $\mathrm{X}$. The material parameters which determine the performance of a TPV cell are: the energy bandgap, $E_{G}$; the optical absorption constant, $\alpha$; the hole, $\mu_{\mathrm{p}}$, and electron, $\mu_{\mathrm{N}}$, carrier mobility; the intrinsic carrier concentration, $\mathrm{n}_{\mathrm{i}}$; 
and the optical index of refraction, $N_{R}$. The following expression given by Roth et al. ${ }^{(4)}$ for the energy bandgap was used:

$$
E_{G}=0.7137-0.9445 X+0.3974 X^{2}
$$

This relationship, depicted in Figure 1, shows that the alloy composition $\mathrm{X}$ for obtaining material with energy bandgaps of $0.6,0.55$ and $0.5 \mathrm{eV}$ are $0.13,0.19$ and 0.25 respectively. Roth et al ${ }^{(4)}$ have also given expressions for the variation of the energy bandgap with temperature as shown in Figure 2 for four different compositions of special interest. The curves in the figures indicate that the variation of $\mathrm{E}_{\mathrm{G}}$ with temperature is very linear and of the order of $0.5 \mathrm{meV} /{ }^{\circ} \mathrm{C}$. If the dark saturation current of GaInSb TPV cells is diffusion limited, then the variation of the open circuit voltage $V_{\mathrm{OC}}$ with temperature is the same as the variation of $\mathrm{E}_{\mathrm{G}}$ and of the order of $0.5 \mathrm{mV} /{ }^{\circ} \mathrm{C}$. If the dark saturation current is limited by generation-recombination in the depletion layer, then the variation of $\mathrm{V}_{\mathrm{OC}}$ with temperature is half of the variation of $\mathrm{E}_{\mathrm{G}}$ with temperature i.e. $0.25 \mathrm{mV} /{ }^{\circ} \mathrm{C}$.

The exact calculation of the absorption constant for a $\operatorname{In}_{x} \mathrm{Ga}_{1-\mathrm{x}} \mathrm{Sb}$ alloy is rather complicated, requiring knowledge of the variation of the critical points of the band structure with alloy composition. A simpler approach, which has shown to be valid for AlGaAs alloys, is to consider only the most important critical point of the band structure, namely the energy bandgap. Using this procedure the absorption constant of the alloy can be calculated from the experimentally determined absorption constant of $\mathrm{GaSb}$ and $\mathrm{InSb}$. The absorption constant $\alpha(\mathrm{E})$ of an $\mathrm{In}_{\mathrm{x}} \mathrm{Ga}_{1-\mathrm{x}} \mathrm{Sb}$ alloy with energy bandgap $E_{G}$ is obtained from the absorption constant, $\alpha_{1}(E)$, of InSb with energy bandgap $E_{1}$; and from the absorption constant, $\alpha_{2}(E)$, of GaSb with energy gap $E_{2}$ using the equation:

$$
\alpha(E)=X \cdot \alpha_{1}\left(E-E_{G}+E_{1}\right)+(1-X) \cdot \alpha_{2}\left(E-E_{G}+E_{2}\right)
$$

Figure 3 shows the experimental absorption constants of $\mathrm{GaSb}$ and $\mathrm{InSb}$ given by Seraphin and Bennett ${ }^{(5)}$ and the calculated absorption constant of $\operatorname{In}_{\mathrm{x}} \mathrm{Ga}_{1-\mathrm{X}} \mathrm{Sb}$ alloy with energy bandgap of 0.55 $\mathrm{eV}(\mathrm{X}=0.19)$.

Notice that the total distance for photon absorption in the alloy is longer than in GaSb and shorter than in InSb. The GaInSb cells require between 5 to 10 microns of semiconductor material for total photon absorption; therefore, the minority carrier diffusion in that active region should be at least comparable for good collection efficiency. For example, GaAs solar cells have a photon absorption depth of approximately 1 micron, and the diffusion length of minority carriers for good collection efficiency is also approximately 1 micron.

The carrier mobility of ternary alloys is difficult to model since disordered alloy scattering, a rather complex theoretical problem must be taken into account. Since the simulation of the TPV cells is not dependent upon the exact value of the carrier mobility, Matthiessen's rule was used to calculate the mobility of the alloy:

$$
\frac{1}{\mu_{\mathrm{ALLOY}}}=\frac{\mathrm{X}}{\mu_{\mathrm{InSb}}}+\frac{(1-\mathrm{X})}{\mu_{\mathrm{GaSb}}}
$$


The carrier mobilities of $\mathrm{InSb}$ and $\mathrm{GaSb}$ were taken from experimental data and fitted to the following empirical equation: ${ }^{(6,7,8)}$

$$
\mu=\mu_{\mathrm{MIN}}+\frac{\mu_{\mathrm{MAX}}-\mu_{\mathrm{MIN}}}{\left(1+\frac{\mathrm{N}}{\mathrm{N}_{\mathrm{REF}}}\right)^{\mathrm{A}}}
$$

where $\mathrm{N}$ is the impurity concentration and the other constants are listed in Table I for InSb and GaSb materials:

Table I

\begin{tabular}{||c|c|c|c|c|}
\hline Material/Carrier & $\begin{array}{c}\mu_{\mathrm{MNN}} \\
\left(\mathrm{cm}^{2} / \mathrm{V}-\mathrm{s}\right)\end{array}$ & $\begin{array}{c}\mu_{\mathrm{MAX}} \\
\left(\mathrm{cm}^{2} / \mathrm{V}-\mathrm{s}\right)\end{array}$ & $\begin{array}{c}\mathrm{N}_{\mathrm{REF}} \\
\left(\mathrm{cm}^{3}\right)\end{array}$ & $\begin{array}{c}\mathrm{A} \\
-\end{array}$ \\
\hline $\mathrm{InSb} / \mathrm{h}$ & $10^{2}$ & $7.5 \times 10^{2}$ & $6 \times 10^{1 /}$ & 0.6 \\
\hline $\mathrm{InSb} / \mathrm{e}$ & $5 \times 10^{3}$ & $7.8 \times 10^{4}$ & $7 \times 10^{16}$ & 0.7 \\
\hline $\mathrm{GaSb} / \mathrm{h}$ & 70 & $1.4 \times 10^{3}$ & $2 \times 10^{1 /}$ & 0.5 \\
\hline $\mathrm{GaSb} / \mathrm{e}$ & $10^{2}$ & $4.5 \times 10^{5}$ & $8 \times 10^{17}$ & 0.8 \\
\hline
\end{tabular}

Plots of the electron and hole mobilities for $\operatorname{In}_{\mathrm{x}} \mathrm{Ga}_{1-\mathrm{x}} \mathrm{Sb}$ alloys of several compositions are given in Figures 4 and 5 . Note that alloy scattering is not included.

The intrinsic carrier concentration, $\mathbf{n}_{\mathrm{i}}$, is another material parameter which is needed to properly simulate a TPV cell. The intrinsic carrier concentration of a direct bandgap semiconductor with parabolic energy bands is given by:

$$
\mathbf{n}_{i}^{2}=\mathrm{N}_{\mathrm{c}}(\mathrm{X}) \mathrm{N}_{\mathrm{v}}(\mathrm{X}) \exp -\frac{\mathrm{E}_{\mathrm{G}}(\mathrm{X})}{\mathrm{kT}}
$$

where $\mathrm{N}_{\mathrm{C}}(\mathrm{X})$ and $\mathrm{N}_{\mathrm{V}}(\mathrm{X})$ are the density of states of the conduction and valence band, respectively and $X$ is the alloy composition. Since the density of states have a $3 / 2$ power dependence upon the effective masses, the variation of the electron and hole effective masses with alloy composition $\mathrm{X}$ is required to calculate $n_{\mathrm{i}}$. A possible way to calculate this variation is to use the equation: ${ }^{(9)}$

$$
\frac{1}{\mathrm{~m}_{\text {ALOY }}^{*}}=\frac{\mathrm{X}}{\mathrm{m}^{*}{ }_{\text {InSb }}}+\frac{(1-X)}{\mathrm{m}^{*} \text { GaSb }}
$$

which is based on the $k p$ method of calculating energy bands. The effective masses used for electrons and holes in InSb and GaSb are given in Table II.

Table II

\begin{tabular}{|c|c|c|}
\hline Material & Electron Effective Mass & Hole Effective Mass \\
\hline InSb & $0.0145 \mathrm{~m}_{0}$ & $0.40 \mathrm{~m}_{0}$ \\
\hline $\mathrm{GaSb}$ & $0.042 \mathrm{~m}_{0}$ & $0.40 \mathrm{~m}_{0}$ \\
\hline
\end{tabular}

In the calculation of the intrinsic carrier concentration, the contribution from the conduction energy band minima located at the L symmetry point of the Brillouin zone was neglected. This assumption 
is reasonable since the separation between this minima and the one located at the center of the Brillouin zone $(\Gamma)$ increases appreciable for alloys with bandgap lower than $0.6 \mathrm{eV}$. A plot of the intrinsic carrier concentration as a function of alloy composition is given in Figure 6.

The last parameter that is useful for calculating the amount of radiation reflected by the semiconductor alloy is the optical index of refraction. In InSb the index of refraction varies from 4.24 at 1 micron to 3.95 at 10 microns. In $\mathrm{GaSb}$ the corresponding values are 4.12 at 1 micron and 3.84 at 10 microns. The variation of this parameter is given in Figure 7 for InSb and GaSb. Since the variation is so small and the values are very close to each other, a linear interpolation with alloy composition is considered a reasonable approximation.

\section{SIMULATION OF $\operatorname{In}_{\mathrm{x}} \mathrm{Ga}_{1-\mathrm{x}}$ Sb TPV CELLS}

The performance of TPV cells illuminated by blackbody thermal sources of known temperature can be calculated from the material parameters of the $\operatorname{In}_{\mathrm{X}} \mathrm{Ga}_{1-\mathrm{X}} \mathrm{Sb}$ as function of alloy composition. Figure 8 shows the structure assumed for the TPV cell which consists of four uniformly doped regions; that is, a neutral emitter region of length $\mathrm{W}_{\mathrm{E}}$, a depletion layer of width $\mathrm{W}_{\mathrm{D}}$, a neutral base region of length $\mathrm{W}_{\mathrm{B}}$ and a heavily doped substrate. Additional parameters which are needed for calculating the performance of the TPV cell are the recombination velocity, $S_{E}$, at the emitter surface; the recombination velocity, $S_{B}$, at the base substrate interface; the diffusion length of minority carriers at the emitter, $\mathrm{L}_{\mathrm{E}}$; and the diffusion length, $\mathrm{L}_{\mathrm{B}}$, of minority carriers in the base.

The total internal quantum efficiency $Q(\lambda)$ as function of wavelength $\lambda$ is the sum of the quantum efficiencies of the emitter $Q_{E}(\lambda)$, of the depletion layer $Q_{D}(\lambda)$ and of the base $Q_{B}(\lambda)$ :

$$
Q(\lambda)=Q_{E}(\lambda)+Q_{D}(\lambda)+Q_{B}(\lambda)
$$

For uniformly doped regions, closed form expressions for each of the above quantum efficiencies are well known. ${ }^{(9)}$ A computer program was developed that calculates the quantum efficiency, the dark J-V characteristics of the cell, the illuminated J-V characteristics when the cell is illuminated with a blackbody of temperature $T_{s}$, the fill factor and the maximum output power density. This model does not include series resistance but additional software can take into account any series or shunt resistance for a cell in which the dark J-V characteristics as well as the photocurrent produced by the blackbody radiation source are known. The validity of such an approach needs to be validated experimentally and can only be considered as a first-order approximation with InGaSb devices at this time.

The surface and interface recombination velocities $\left(S_{E}\right.$ and $\left.S_{B}\right)$ and the emitter and base diffusion lengths $\left(\mathrm{L}_{\mathrm{F}}\right.$ and $\mathrm{L}_{\mathrm{B}}$ ) depend not only upon the doping, but also upon the quality of both the semiconductor alloy material and the device processing. Although values of these parameters are not known apriori, their range can be bounded. For a good surface or interface, the value of the recombination velocity is of the order of $10^{3} \mathrm{~cm} / \mathrm{sec}$ and for a bad surface or interface the value is of the order of $10^{6}$ to $10^{7} \mathrm{~cm} / \mathrm{sec}$. The minority carrier diffusion length is more difficult to bound, but an upper limit to the minority carrier lifetime is given by the radiative recombination limit. ${ }^{(10)}$

The excess carrier lifetime in the radiative recombination limit was calculated as a function of the alloy composition for carrier densities of $10^{15}, 10^{16}$ and $10^{17} \mathrm{~cm}^{-3}$ as shown in Figure 9 . For a given alloy composition, the radiative recombination lifetime is inversely proportional to the doping concentration and increases as the bandgap decreases. This figure and the carrier mobilities given in Figures 4 and 5 can be used for determining upper bounds to the diffusion length of minority carriers given a doping concentration and an alloy composition. 


\section{SIMULATION RESULTS}

Using the computer program the efficiency of $\mathrm{N}^{+} \mathrm{P}$ and $\mathrm{P}^{+} \mathrm{N}$ cells with an energy band gap of $0.55 \mathrm{eV}$ was optimized when illuminated by a $1500^{\circ} \mathrm{K}$ blackbody radiation source. In order to reduce the parameters to be optimized, the surface emitter and base interface recombination velocities have been assumed to have a low value of $10^{3} \mathrm{~cm} / \mathrm{sec}$. The minority lifetime has been set to the upper-bound radiative recombination limit and is determined by the doping in that region. Also the depletion layer width has been set to be 0.1 micron, independent of the emitter and base doping. With these assumptions, the efficiency depends only upon four parameters: the widths of the emitter and base regions $\left(W_{E}\right.$, and $\left.W_{B}\right)$ and the doping concentrations $\left(N_{E}\right.$, and $\left.N_{B}\right)$ in the same regions. The optimum values obtained for these parameters for achieving maximum efficiency are given in Table III and depend upon the type of cell. Note that the diffusion length in the base, $\mathrm{L}_{B}$, is significantly greater than the diffusion length in the emitter, $\mathrm{L}_{\mathrm{E}}$, since the emitter doping is at least a order of magnitude greater than the base doping.

Table III

\begin{tabular}{||c|c|c|c|c|c|c|}
\hline Cell Type & $\begin{array}{c}\mathrm{N}_{\mathrm{E}_{3}} \\
\left(\mathrm{~cm}^{-3}\right)\end{array}$ & $\begin{array}{c}\mathrm{N}_{\mathrm{B}^{-3}} \\
\left(\mathrm{~cm}^{-3}\right)\end{array}$ & $\begin{array}{c}\mathrm{W}_{\mathrm{E}} \\
(\mu \mathrm{m})\end{array}$ & $\begin{array}{c}\mathrm{W}_{\mathrm{B}} \\
(\mu \mathrm{m})\end{array}$ & $\begin{array}{c}\mathrm{L}_{\mathrm{E}} \\
(\mu \mathrm{m})\end{array}$ & $\begin{array}{c}\mathrm{L}_{\mathrm{B}} \\
(\mu \mathrm{m})\end{array}$ \\
\hline $\mathrm{N}^{+} \mathrm{P}$ & $5 \times 10^{18}$ & $10^{17}$ & 0.1 & 7 & 1 & 30 \\
\hline $\mathrm{P}^{+} \mathrm{N}$ & $10^{18}$ & $5 \times 10^{16}$ & 0.7 & 6 & 7 & 19 \\
\hline
\end{tabular}

The efficiency achieved without any below-bandgap filter and with an ideal below-bandgap filter as well as the associated output power density are given in Table IV. An ideal belowbandgap filter reflects all photons with energy below the bandgap to the thermal radiator where these photons are assumed to be recycled without energy loss. In both cases an ideal matching filter for above-bandgap radiation has been assumed. The open circuit voltage is $0.35 \mathrm{eV}$ and the fill factor is $0.74 \mathrm{eV}$ for these conditions.

Table IV

\begin{tabular}{|c|c|c|c|}
\hline Cell Type & $\begin{array}{c}\text { Efficiency without } \\
\text { Filter } \\
\text { Below-Bandgap } \\
(\%)\end{array}$ & $\begin{array}{c}\text { Efficiency with Ideal } \\
\text { Filter } \\
\text { Below-Bandgap } \\
(\%)\end{array}$ & $\begin{array}{c}\text { Output Power Density } \\
\left(\mathrm{W} / \mathrm{cm}^{2}\right)\end{array}$ \\
\hline $\mathrm{N}^{+} \mathrm{P}$ & 12 & 36. & 3.5 \\
\hline $\mathrm{P}^{+} \mathrm{N}$ & 12 & 35. & 3.5 \\
\hline
\end{tabular}

The results given in Table IV show that $\mathrm{N}^{+} \mathrm{P}$ and $\mathrm{P}^{+} \mathrm{N}$ cell are capable of achieving the same upper bound to efficiency and output power density if properly optimized. Furthermore, the results of Table III indicate that the total active region of the cell should be of the order of 7 microns, with the doping in the emitter of the order of $10^{18} \mathrm{~cm}^{-3}$ and in the base of the order of $10^{17} \mathrm{~cm}^{-3}$. These design values assume that radiative recombination is limiting. Devices fabricated in GaSb and InGaSb to date have lower diffusion lengths.

\section{CONCLUSIONS}

In this paper we have presented the methodology used for obtaining the material parameters of $\mathrm{In}_{\mathrm{x}} \mathrm{Ga}_{1-\mathrm{X}} \mathrm{Sb}$ alloys which are important for calculating the performance and efficiency of TPV cells. Using these material parameters the influence of many of the cell parameters on cell efficiency and performance can be evaluated. Assuming low values of surface recombination velocity and assuming the lifetime to be limited by radiative recombination, a closed form computer model is used to optimize a cell of $0.55 \mathrm{eV}$ bandgap illuminated by a blackbody radiation source at 
$1500^{\circ} \mathrm{K}$. The maximum possible efficiency is independent of the cell type, $\mathrm{N}^{+} \mathrm{P}$ or $\mathrm{P}^{+} \mathrm{N}$, and equal to $12 . \%$ without any below-bandgap filter and $36 . \%$ with an ideal below-bandgap filter which reflects all the below-bandgap radiation to the thermal radiator in a reusable form. Factors such as series resistance and non-diffusive junction current (eg. tunneling current) will reduce these upperbound values in actual devices, as well as the mobility and lifetime assumptions explicity indicated previously.

\section{REFERENCES}

1. P.F. Baldasaro et al., 1st NREL Conference on Thermophotovoltaic Generation of Electricity, AIP Proceedings 321, 29, (1994).

2. M. Zierak, et al., 1st NREL Conference on Thermophotovoltaic Generation of Electricity, AIP Proceedings 321, 457, (1994).

3. S. Wojtczuk, 1st NREL Conference on Thermophotovoltaic Generation of Electricity, AIP Proceedings 358, 387, (1995).

4. A.P. Roth et al., Canadian Journal of Physics, 58, 560, (1980).

5. B.O. Seraphin and H.E. Bennett in Semiconductors and Semimetals Vol. 3, R.K. Willardson and A.C. Beer, eds., Academic Press, New York, 1967, p. 469.

6. J.D. Wiley, Semiconductors and Semimetals Vol.10, R.K. Willardson and A.C. Beer, eds., Academic Press, New York 1975, p. 154,157

7. C. Hilsum and A.C. Rose-Innes, Semiconducting III-V Compounds, Pergamon Press, New York, 1961, p. 128-140.

8. A.G.Milnes and A.Y.Polyakov, Solid State Electronics Journal, 36, 803, (1993).

9. S.M. Sze, Physics of Semiconductor Devices, 2nd. Edition, J. Wiley and Sons, New York, 1981, p. 800.

10. W. Van Roosbroech and W. Shockley, Phs. Rev. 94, p. 1558, (1954). 


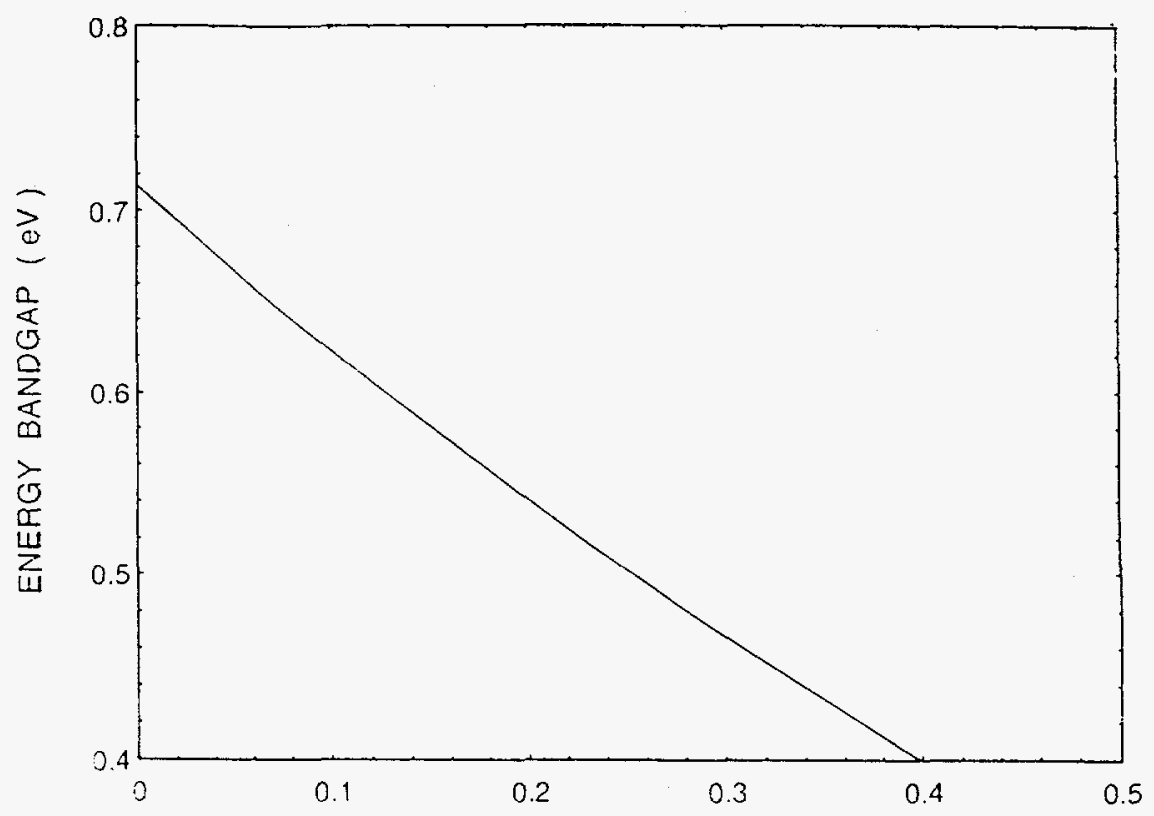

FRACTIONAL COMPOSITION $X$

Figure 1 Energy Bandgap of InGaSb Alloys as Function of Alloy Composition.

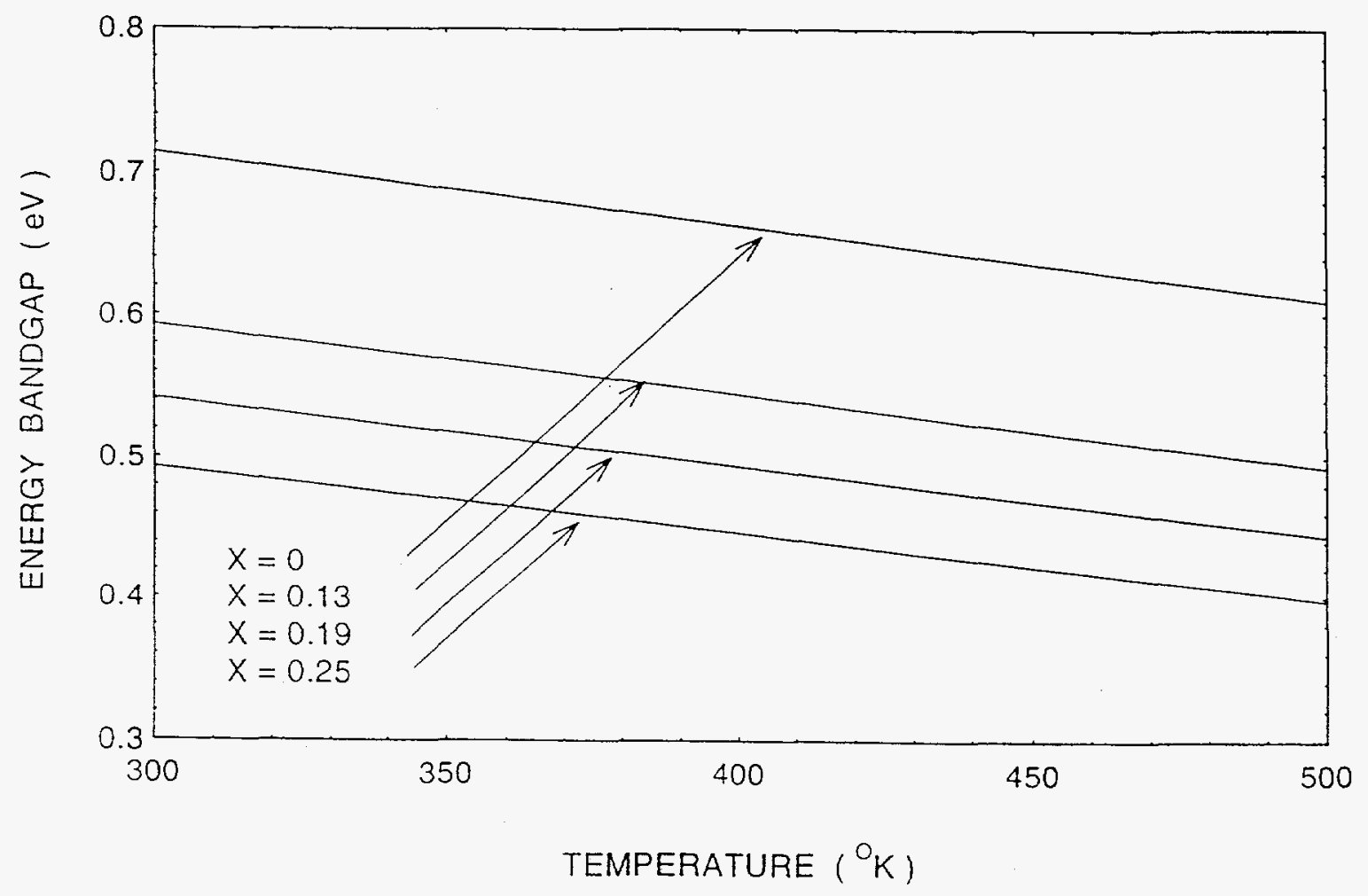

Figure 2 Variation of the Energy Bandgap with Temperature for Several InGaSb Alloys. 


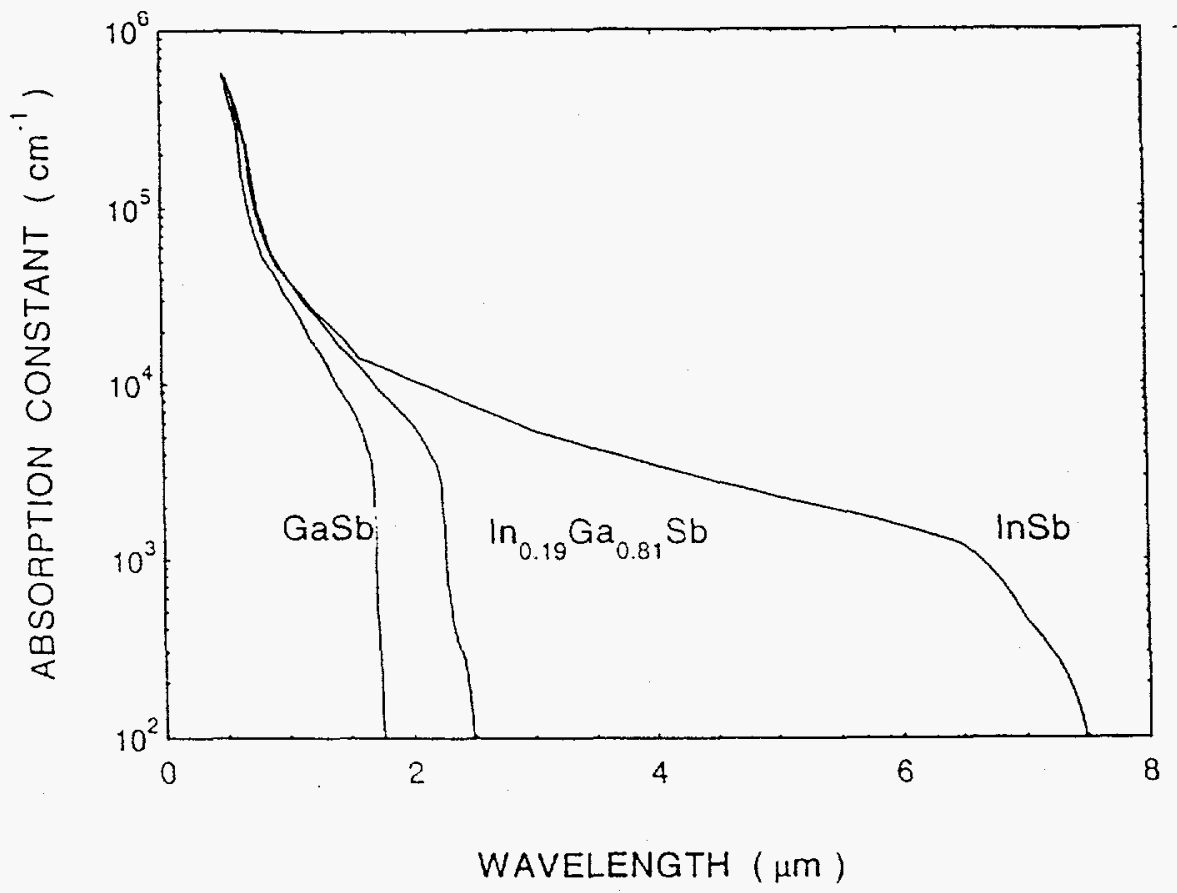

Figure 3 Optical Absorption Constant of an InGaSb Alloy with Energy Bandgap of $0.55 \mathrm{eV}$.

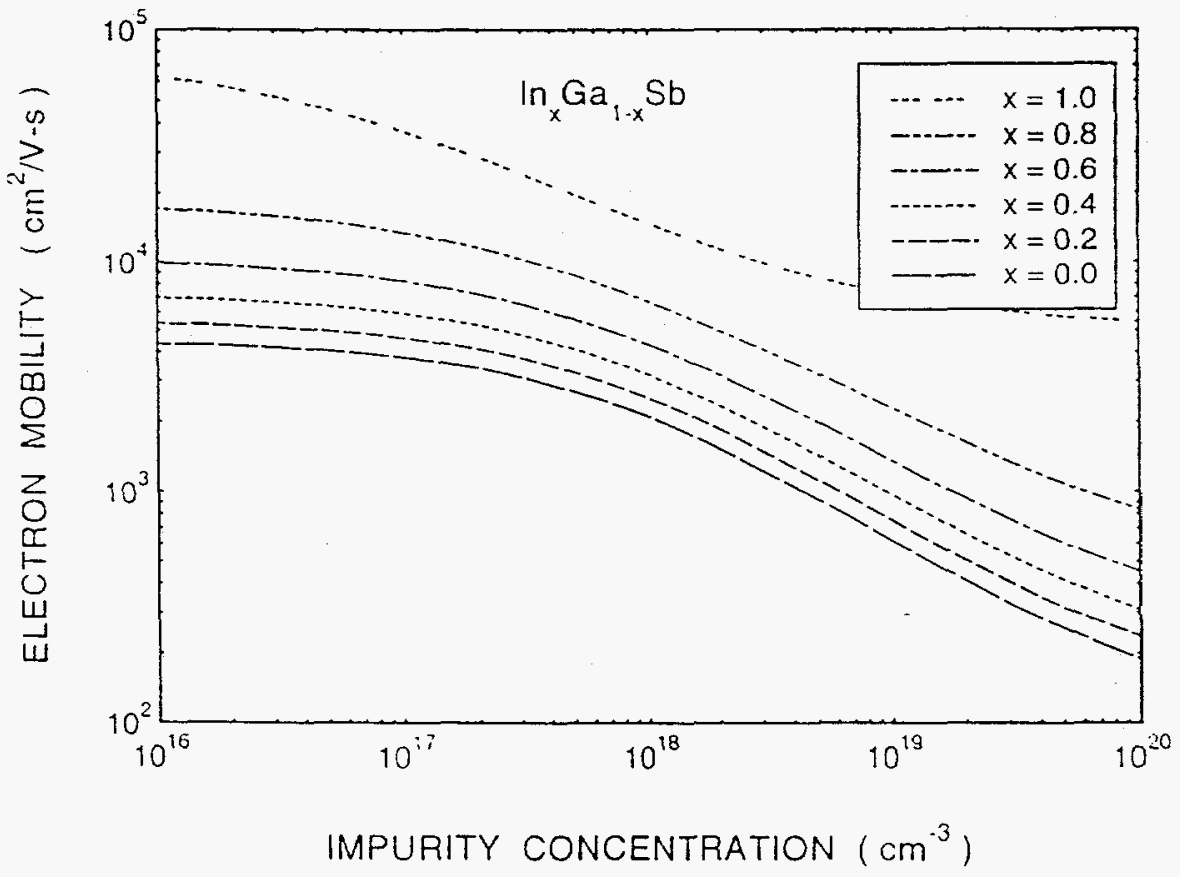

Figure 4 Electron Mobility of InGaSb Alloys as Function of Doping Concentration. 


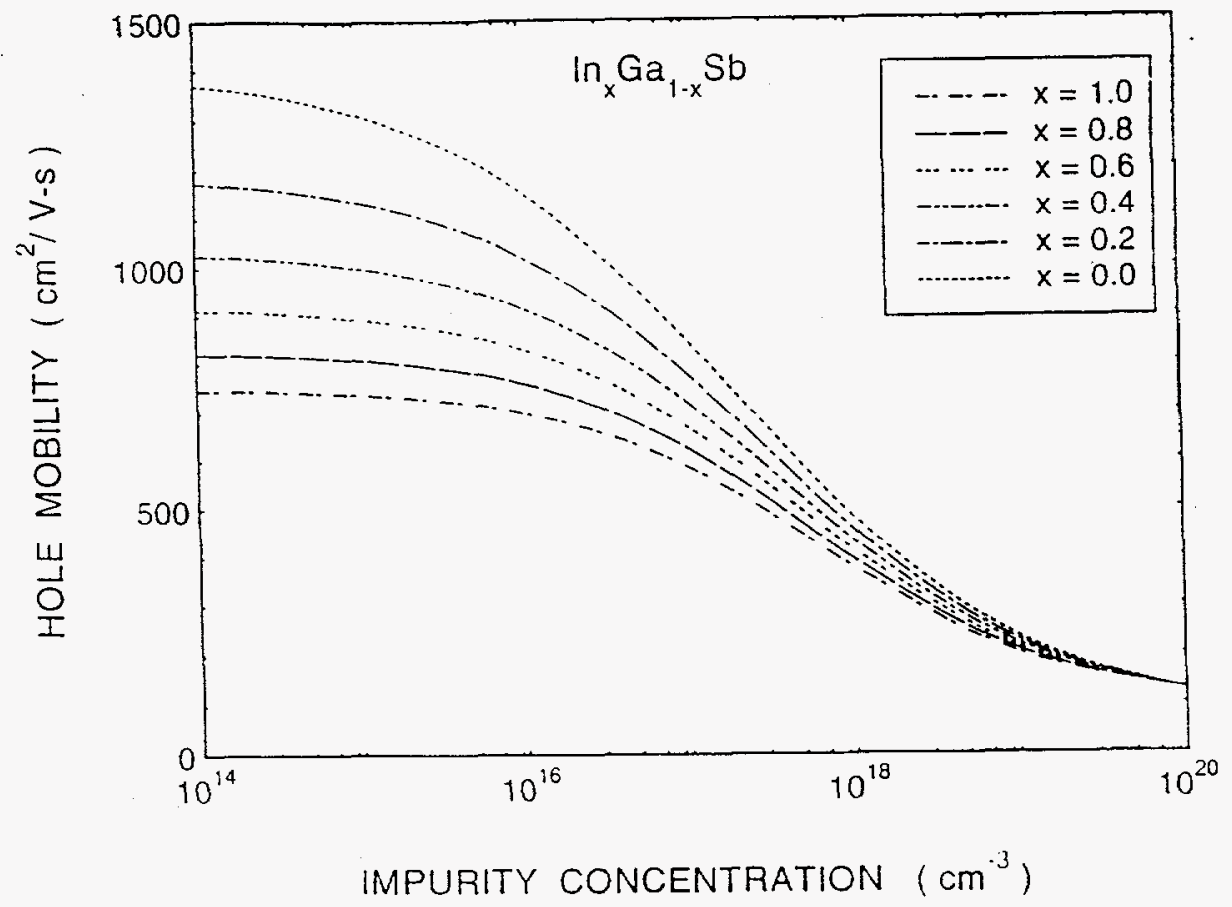

Figure 5 Hole Mobility of InGaSb Alloys as Function of Doping Concentration.

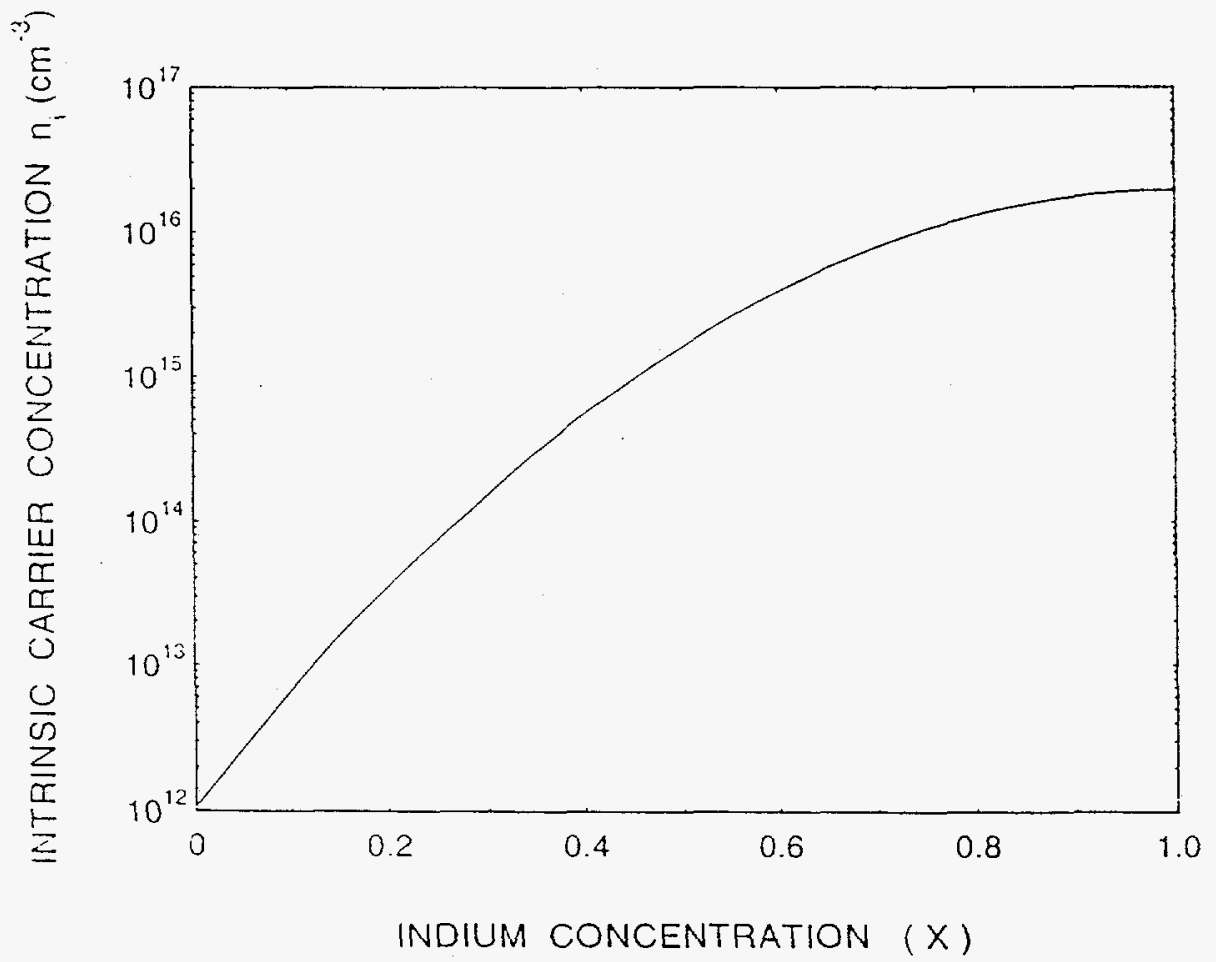

Figure 6 Intrinsic Carrier Concentration at Room Temperature of InGaSb Alloys. 


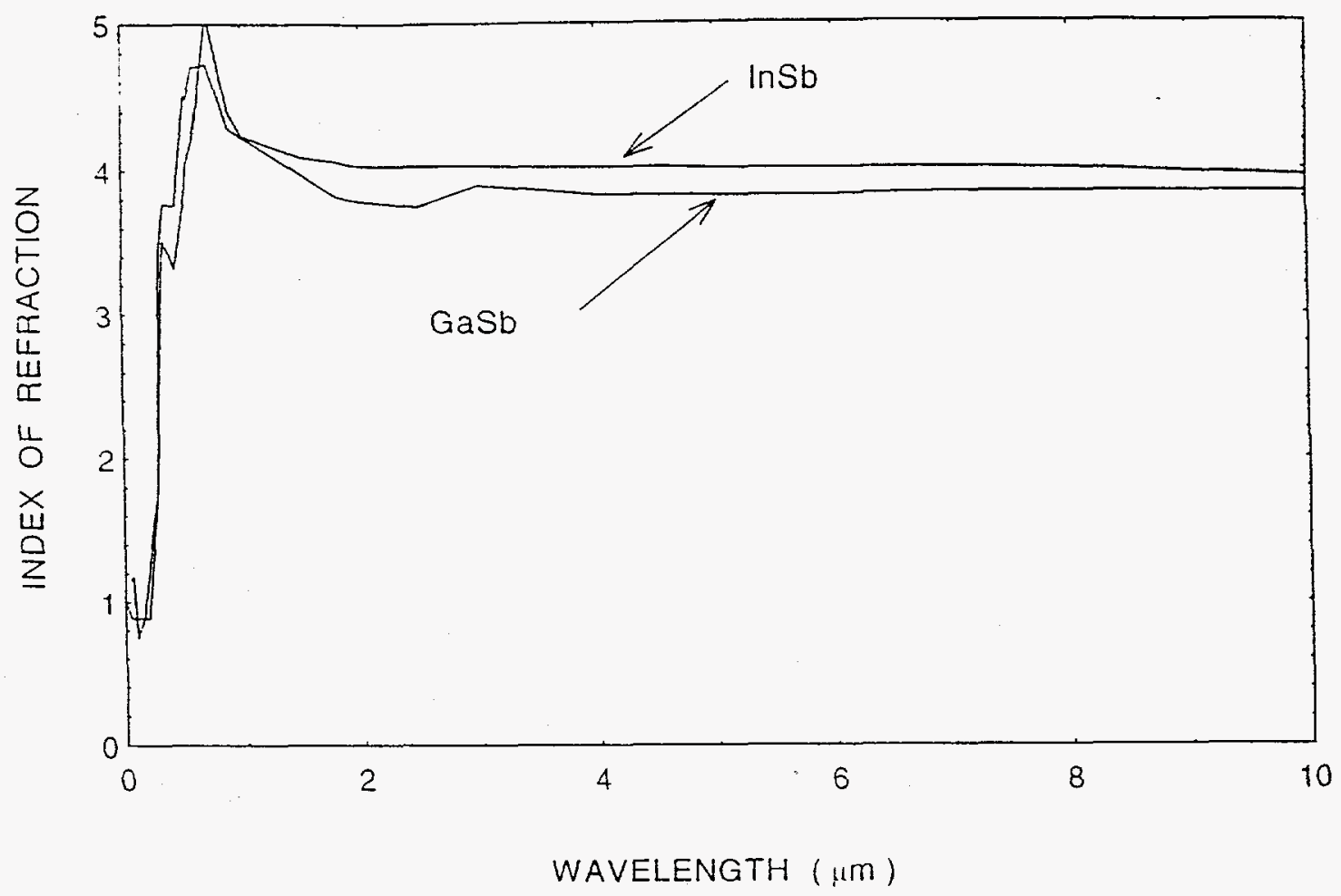

Figure 7 Optical Index of Refraction as Function of Wavelength for InSb and GaSb.

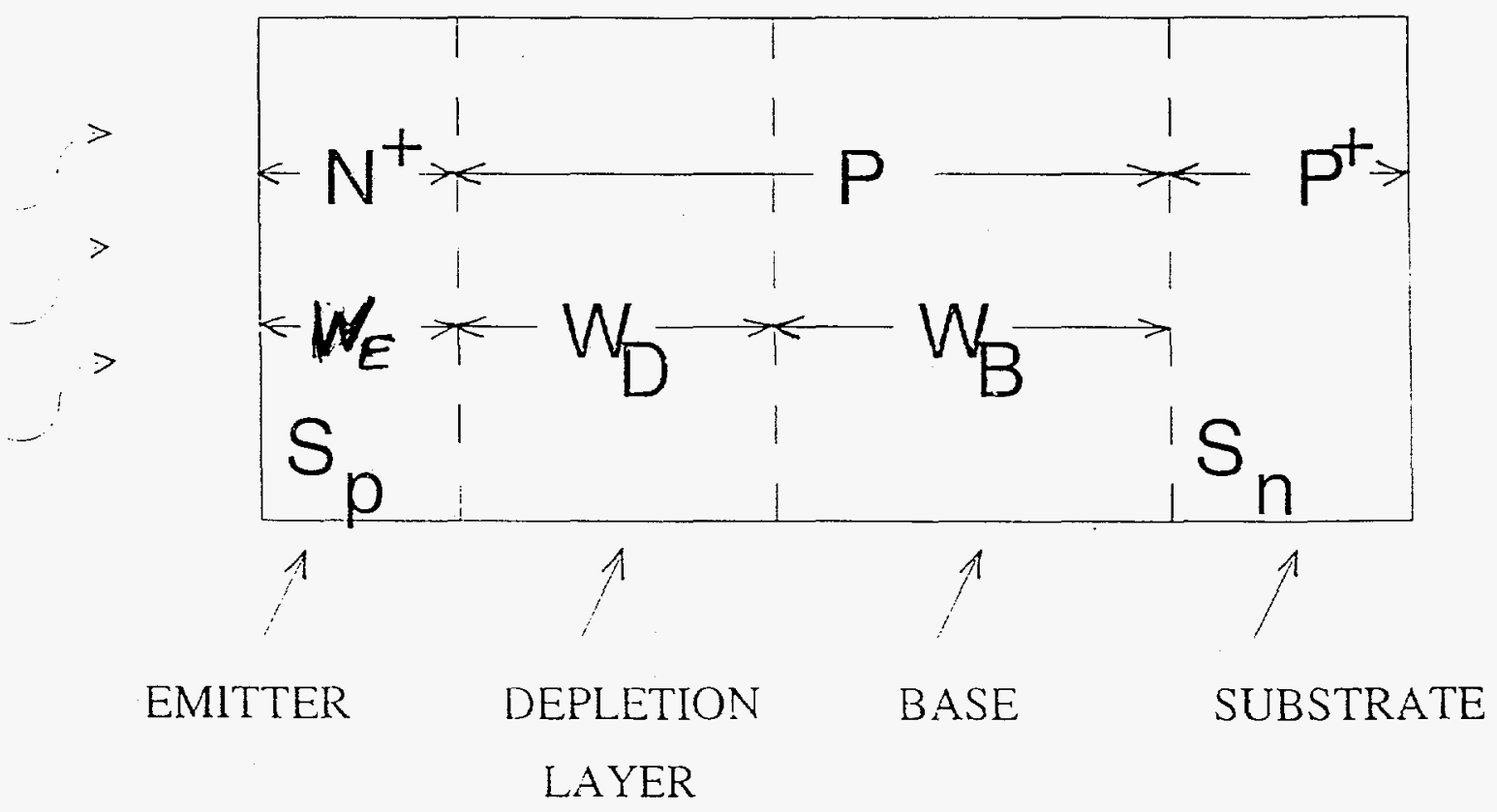

Figure 8 Schematic Diagram of a TPV Cell. 


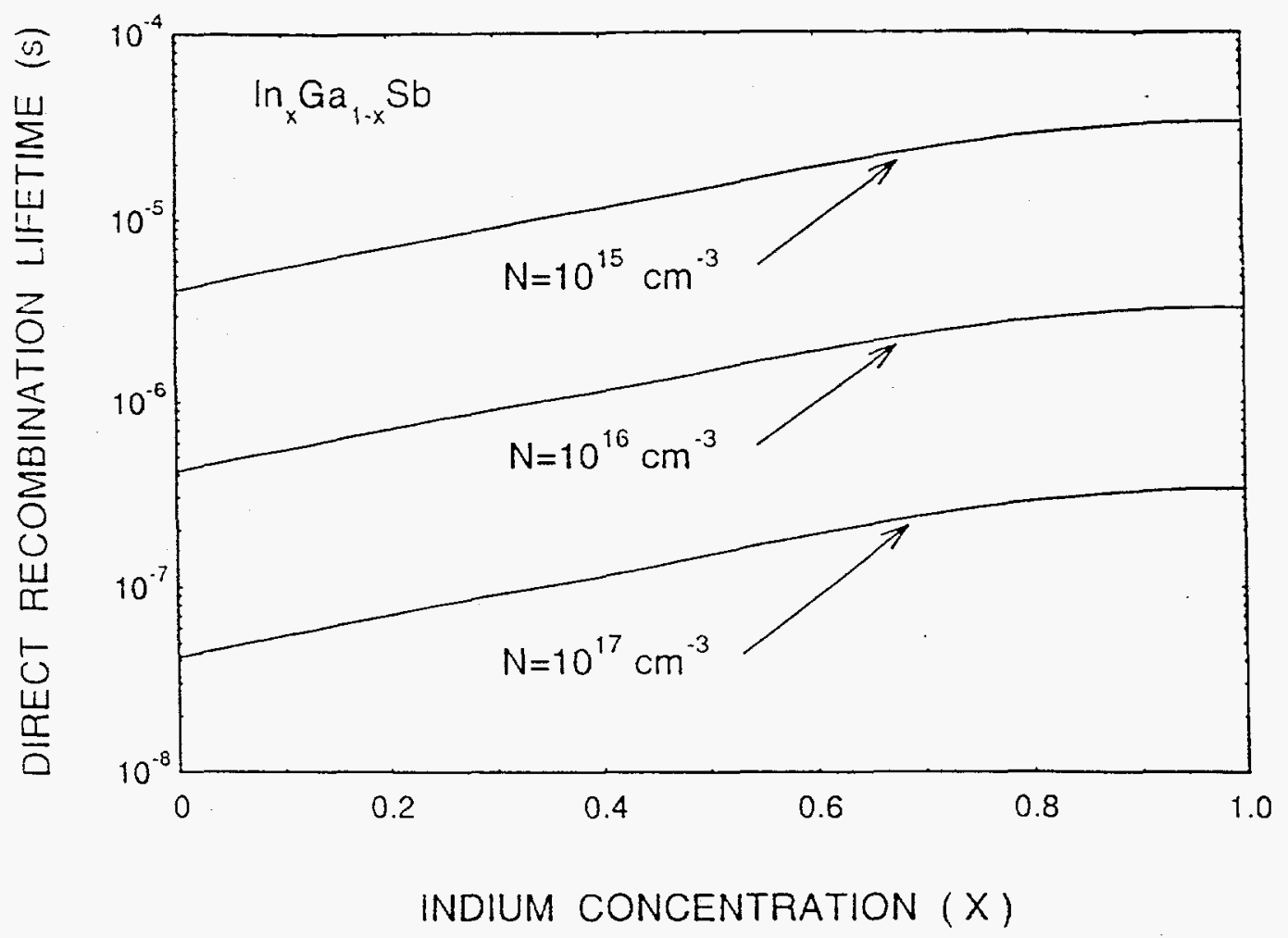

Figure 9 Radiative Recombination Lifetime of $\mathrm{InGaSb}$ as Function of Alloy Composition for Several Doping Concentrations. 